\title{
A DEIXIS ANALYSIS OF A SONG LYRICS ENTITLED "LOVER"
}

\author{
Sofia Fadilah ${ }^{1}$, Setya Resmini ${ }^{2}$ \\ 1,2 IKIP Siliwangi \\ ${ }^{1}$ sofiatulfadilah@student.ikipsiliwangi.ac.id, ${ }^{2}$ setyaresmini@ikipsiliwangi.ac.id
}

\begin{abstract}
This research is a qualitative research which aims to analyze the kinds of dominant deixis in the song lyrics entitled 'Lover'. The data collected from the lyrics then classified into types of deixis according to Levinson (1983:62) theory. The classification of the data then analyzed by relating the deixis to the references/meaning from the lyrics. The result of this research found that there are 51 deixis found in the lyrics consist of 39 personal deixis, 7 temporal deixis, and 5 spatial deixis. Most of personal deixis in 'Lover' lyric refer to the speaker itself which are encoded by first singular personal deixis like I and My. While for first plural personal deixis which is We, mostly refer to the speaker. Finally, this research is expected to provide an understanding of deixis and the context that is conveyed by the speaker.
\end{abstract}

Keywords: Deixis, Pragmatics, Song Lyrics

\section{INTRODUCTION}

Language is a very important tool in life because language refers to the course of communication between humans. According to Lunenburg (2010 as cited Saputri, 2016), the study of communication is very important because some forms of direct or indirect communication exist in any administrative and activity function. Therefore, the language we use is very influential in communication to avoid misunderstanding or interpretation. Furthermore, language is not only used as communication media but also usually involved in other fields such as language and arts. It can be found in advertisement and entertainment which appear in society such as music, novel, film or movie.

One of the entertainment media that is familiar to us is music. According to Juslin and Sloboda, (2010 as cited Nasution, Setiadi, \& Ilza, 2018) music is often described as a "language of emotions". Music is very influental against the emotion of a person by delivering it can immediatelly touch the conscience of someone who is listening. According Hidayah (2019) Music is a basic instinct of human being, a daily basis human activity which is universally engaged with, loved and experienced. Music plays an important role in the formation of a person's identity. In addition, music can inspire listeners who listen to music itself. When music is heard by someone, the people not only finds meaning in the lyrics of the music, but also the meaning of speaker means. Then, the study of what speakers mean or speaker meaning is being disussed in pragmatics.

Pragmatics is the study of aspects of the use of meaning and language that depend on speakers, receivers and the context of other features of speech. Yule (1996 as cited Hidayah, 2019), defines that pragmatis is closely relate to the study of meaning. Meaning is the information or concepts that a sender intends to convey, or does convey, in communication with a receiver. Communication will help someone to avoid misunderstanding. When realizing that 
understanding is very important in communication, the reader or listener must be able to identify the context of utility.

According to Yule (1996 as cited Hidayah, 2019), Deixis is one of the most basic things in technical term of utterances. The word 'deixis' is borrowed from the Greek word for pointing or indicating. Additionally Levinson (1983 as cited Hidayah, 2019), states that deixis directly concerns with the relationship language and context which is reflected in structures of language theirselves. Furthermore, Levinson (1983:62) classifies deixis into five parts, namely personal deixis, spatial deixis, temporal deixis, social deixis, and discourse deixis.

In this study, the researcher wants to analyze deixis in song lyrics of 'Lover' by Taylor Swift, not only because it has deictic words but also many people especially teenagers are interested in this song. The aims of the research are to identify the kinds of deixis that are used in the song lyrics in 'Lover' and to find out the dominant types of deixis that are used in the song lyrics in 'Lover'. The focus of this study is to investigate deixis in the song lyrics of 'Lover' using pragmatic approach. The researcher hopes that it can help the listeners easily to understand the use and the meaning of deixis, especially in song lyric.

\section{METHOD}

This study applies a descriptive qualitative method. Which uses lyris from a song entitled 'Lover' as the research data source. Apsari (2017 as cited Liawati, Rizkiani, \& Jamaludin, 2020), states that qualitative research is syntheticor holistic, heuristic, with little or no control and manipulation of the research content.

In addition, Santosa (2012 as cited Hidayah, 2019) states that data is object of research or the reality that is made the focus of research. The researcher took data from the Taylor Swift song lyrics titled 'Lover'. The track was then released as a single onto iTunes on August $23^{\text {rd }} 2019$ is chosen as the subject of this study and used as data.

Researcher collects data by doing steps, According to Hidayah (2019) says that there is several stpes in collecting data as follow :

1. The researcher listened to the songs in order to understand the lyrics in detail.

2. The researcher searched the script of the lyrics on internet.

3. The researcher marked all of the chosen lyrics to be analyzed.

After the data is collected, the researcher analyzes the data by selecting some of the lyrics that has the deixis expression to be analyzed. Finally, the researcher describes the types of deixis that have been selected.

\section{RESULTS AND DISCUSSION}

\section{Results}

Based the analysis, the researcher found that the lyrics tend to use such types of deixis which includes personal deixis, temporal deixis, and spatial deixis in 'Lover' song lyrics. The types of deixis used are various and have different references and meanings.

\begin{tabular}{cccc}
\hline \multirow{2}{*}{ The lyric } & \multicolumn{3}{c}{ Types of deixis } \\
\cline { 2 - 4 } & personal & Temporal & Spatial \\
\hline
\end{tabular}




\begin{tabular}{|c|c|c|c|}
\hline $\begin{array}{l}\text { "We could leave the } \\
\text { Christmas lights up } \\
\text { 'til January" }\end{array}$ & $\mathrm{We}$ & Christmas, January & - \\
\hline $\begin{array}{l}\text { This is our pllace, we } \\
\text { make thhe rulees }\end{array}$ & Our, We & & place \\
\hline $\begin{array}{l}\text { And "there's a dazling } \\
\text { haze, a mysterius way } \\
\text { aout you, dear" }\end{array}$ & You & - & There \\
\hline $\begin{array}{l}\text { Have "I know you } \\
\text { tweny seconds or } \\
\text { twenty yers?" }\end{array}$ & I, You & $\begin{array}{l}\text { Twenty second, } \\
\text { Twenty years }\end{array}$ & - \\
\hline $\begin{array}{l}\text { Can "I go whre you } \\
\text { go?" }\end{array}$ & I, You & - & - \\
\hline $\begin{array}{l}\text { "Can we always be } \\
\text { ths clos forevr and } \\
\text { ever?" }\end{array}$ & $\mathrm{We}$ & Forever & - \\
\hline $\begin{array}{l}\text { "And ah, take me out, } \\
\text { and takke me home" }\end{array}$ & $\mathrm{Me}, \mathrm{Me}$ & - & Home \\
\hline $\begin{array}{l}\text { "You're my3x my } \\
\text { lover" }\end{array}$ & You, My(3x) & - & - \\
\hline $\begin{array}{l}\text { We "could let our } \\
\text { friennds crsh in the } \\
\text { livin room" }\end{array}$ & We, our & - & Living room \\
\hline $\begin{array}{l}\text { This "is ourt placve, } \\
\text { we make the call" }\end{array}$ & Our, We & - & place \\
\hline $\begin{array}{l}\text { And "I'm highly } \\
\text { suspicius that } \\
\text { everyone who ses yo } \\
\text { want you" }\end{array}$ & I, You, You & - & - \\
\hline $\begin{array}{l}\text { I've "loved you thhree } \\
\text { sumers now, honey, } \\
\text { but I waant m all" }\end{array}$ & I, You,I & Three summer, Now & - \\
\hline $\begin{array}{l}\text { Ladies "and } \\
\text { gentlemen, will you" } \\
\text { please stand?" }\end{array}$ & You & - & - \\
\hline $\begin{array}{l}\text { With "every guitar } \\
\text { strinng sczar on my } \\
\text { hand" }\end{array}$ & My & - & - \\
\hline $\begin{array}{l}\text { I "take this magnetc } \\
\text { force of man to be my } \\
\text { lover" }\end{array}$ & $\mathrm{I}, \mathrm{My}$ & - & - \\
\hline $\begin{array}{l}\text { My "heart's been } \\
\text { borowed and yous has } \\
\text { ben blue" }\end{array}$ & My, Yours & - & - \\
\hline $\begin{array}{l}\text { All's "well tht end } \\
\text { well to end up with } \\
\text { you" }\end{array}$ & You & - & - \\
\hline
\end{tabular}




\begin{tabular}{lccc}
\hline $\begin{array}{l}\text { Swear "to be } \\
\text { overdrmatic and true } \\
\text { to mmy lover" }\end{array}$ & My & - & - \\
\hline And "you'll save all & You, Your, Me & - & - \\
your dirties jokews & & & - \\
for me" & & - & \\
\hline $\begin{array}{l}\text { And "at evey tablle, } \\
\text { Ill save you seat, }\end{array}$ & I, You & & \\
lover" & & & \\
\hline
\end{tabular}

\section{Discussion}

From the data, there are three types of deixis found by researcher. Consist of ; personal, temporal and spatial deixis. (Levinson in pratiwi, 2018) The deixis found in the lyrics will be discussed in the following discussion.

\section{Personal Deixis}

Personal deixis is the type of deixis that indicate to the people, and sometimes it refers to pronoun. According to Levinson (1983: 62), personal deixis issues the encoding of the position of individuals withinside the speech occasion wherein the utterance in query is delivering there are 39 personal deixis in the lyris. Yule (1996: 10), states that personal Deixis definitely operates on a primary three-element division, exemplified via way of means of the pronouns for the primary person ('I'), 2nd person ('you'), and 1/3 person ('he', 'she', or 'it'). In this study, There are two types of personal deixis used in lover songs, namely first person and second person.

a) First person

According to Levinson (1983:62), the category the primary character deixis is the grammaticalization of the speaker referents to himself. First person (I/We) Deixis is a reference that refers to the speaker or each speaker and referent grouped with the speaker that's expressed in singular pronouns such as I, mine, myself, me and plural pronouns such as us, our, we, ourselves, ours. ). there are 15 person deixis in the lyrics. One of them can be seen in the following sentence: We could leave the Christmas lights up 'til January The word We in the sentence above is the first personal deixis, because it refers to someone who will do something. b) Second person

The second personal deixis Is a deictic connection with someone or humans recognized as addressee, such as you, yours, yourselves, your,yourself . Levinson (1983:62), Defines that second person is the encoding of the speaker's connection with one or more addressee. There are 11 second person deixis in the lyrics. One of them the second deixis can found in this sentence : Have I know you twety seconds or twenty years?. The word you in the sentence above is the second person deixis.

\section{Spatial Deixis}

According to Levinson (1983 as cited Ainiyah, Sili, \& Ariani, 2019) Spatial deixis is also described as spatial deixis, wherein the relative vicinity of humans and matters is being indicated. Below this is spatial deixis which is found by the researcher and the data taken are limited and adjusted to the internal example theory. There are s spatial deixis in the lyrics. On of them can be seen in the sentence: And there's a dazzling haze, a mysterious way about you, dear. There refers to somewhere. The function of spatial deixis is to indiicate the use of the distance or location in the song lyrics. 


\section{Temporal Deixis}

According to Levinson theory (1983 as cited Sasmita, Hardiah, \& Elfrida, 2018) that temporal deixis is identified by adverbial of time. The researcher found and classified the song which shows that the temporal deixis or time deixis occurs.there are 7 temporal deixis in the lyris. One of them can be seen in this sentence: Can we always be this close forever and ever?.Forever refers to time. Based on the explanation above, the researcher includes that from the song 'Lover', the use of temporal deixis occurs. The function of temporal deixis is to indicate the use of the timing in the song lyrics.

\section{CONCLUSION}

This 'Lover' song uses all types of deixis which are personal, spatial, and temporal deixis. Personal deixis found in this lyrics includes two types of personal deixis which are first personal deixis and second personal deixis. In addition, the other types which are temporal deixis and spatial deixis occur in a song of 'Lover'. Most of personal deixis in 'Lover' song lyric refer to the speaker herself which are encoded by first singular personal deixis like I and My. While for the first plural personal deixis which are We, mostly refer to the speaker. In this research, personal deixis is the most dominant types in the songs. It is because the singer tells about the love feeling to the boy in her song that make the use of personal deixis type are more often than others. The researcher notes that by using the deixis it will make easily to describe the function of personal, pronoun, time, and demonstrative which are connecting the utterance with relation of personal, spatial and temporal. It is also useful to catch the reference meaning that include who, where, and when the utterance is uttered.

\section{ACKNOWLEDGMENTS}

The researcher thanks to Allah SWT for helping to smooth the process of making this journal. I would like to express my deepest gratitude to my parents and my family, who give me support and never stop praying for me. Above all, I would like to thank you to my lecturer, Ms. Setya Resmini M. Pd., for her advices and knowledge of doing research. I would also like to show my gratitude to my beloved friends Jerome/Touluse, and lucky gurls ( $\mathrm{T}$ Winola, Nanda A, Riska FS, Resti, Nikita FK, Kikit M) for sharing their pearls of wisdom, motivations, and entertainment with me during the course of this research.

\section{REFERENCES}

Ainiyah, K., Sili, S., \& Ariani, S. (2019). Analysis of Deixis in Pitch Perfect 2 Movie. Jurnal Ilmu Budaya, 3(3), 288-302.

Hidayah, A. (2019). A Deixis Analysis of Song Lyrics in Back To You. Surakarta, 2(2), 4755.

Levinson, S.C. (1983). Pragmatics. London: Cambridge University Press.

Liawati, A., Rizkiani, S., \& Jamaludin, A. (2020). Deixis in the Clever Servant Story. PROJECT (Professional Journal of English Education), 3(1), 54. https://doi.org/10.22460/project.v3i1.p54-58

Nasution, D. R. A., Setiadi, G., \& Ilza, S. S. (2018). Deixis Analysis in the Song Lyrics of Ed Sheeran's Divide Album. Journal of 2nd English Language and Literature International Conference (ELLiC) Proceedings, 2, 376-382.

Pratiwi, S. (2018). Person Deixis in English Translation of Summarized Shahih Al-Bukhari Hadith in the Book of As-Salat. Advances in Language and Literary Studies, 9(1), 40. https://doi.org/10.7575/aiac.alls.v.9n.1p.40 
Saputri, K. (2016). An Analysis of Deixis in Black Swan Movie Script, 5(1), 13-18.

Sasmita, R., Hardiah, M., \& Elfrida. (2018). An Analysis of Deixis and Its Reference Used By Main Character in "a Thousand Words" Movie Scriptby Steve Koren. Journal of English Education and Teaching, 2(1), 68-75. https://doi.org/10.33369/jeet.2.1.68-75

Yule, G. (1996). Pragmatics. Oxford: Oxford University Press 